\title{
Application of GMPEs to Estimate the Minimum Magnitude and Peak Ground Acceleration of Prehistoric Earthquakes at Hollywood, SC
}

\author{
Emad Gheibi ${ }^{1}$, S.M. ASCE, and Sarah L. Gassman ${ }^{2}$, Ph.D., M. ASCE \\ ${ }^{1}$ Ph.D Candidate, Dept. of Civil Engineering, University of South Carolina, Columbia, SC, USA. \\ 29208, emadgheibi@gmail.com \\ ${ }^{2}$ Corresponding author. Associate Professor, Dept. of Civil Engineering, University of South Carolina, \\ Columbia, SC, USA 29208, gassman@ cec.sc.edu
}

\begin{abstract}
In this study, the minimum earthquake magnitude and peak ground acceleration required to initiate liquefaction at the time of prehistoric earthquakes that date back to 11,000 years before present at the Hollywood site located in the South Carolina Coastal Plain were computed. The soils at this site are estimated to be about 120,000 to 130,000 years old. In-situ geotechnical data, including cone penetration data with pore water pressure measurements, were used with empirical methods that account for the age of the soil deposit to back analyse the peak ground acceleration. Results were then combined with the corresponding values obtained using Ground Motion Prediction Equations (GMPEs) to obtain a proper estimation of $\mathrm{a}_{\max }-\mathrm{M}$ of the prehistoric earthquakes at the Hollywood site. When the age of the earthquake was not considered, the minimum magnitude ranged from 5.8 to 6.5 and the corresponding peak ground acceleration ranged from 0.25 to $0.32 \mathrm{~g}$. When the age of the earthquake was considered, the minimum magnitude was found to be 0.2 to 0.3 units lower depending on earthquake age and the GMPE model. For the most recent
\end{abstract}


prehistoric earthquake with the age of $546 \pm 17$, the minimum magnitude ranged from 5.6 to 6.3 with corresponding acceleration ranging from 0.21 to $0.28 \mathrm{~g}$.

KEYWORDS: Paleoliqufaction; Paleoseismicity; Geotechnical analysis; Earthquake magnitude; Soil aging; South Carolina Coastal Plain

\section{INTRODUCTION}

The South Carolina Coastal Plain (SCCP) experiences infrequent earthquakes, thus paleoliquefaction analysis plays an important role in studying the paleoseismicity of this region. As an example, over 160 paleoliquefaction features have been discovered at a site near Hollywood (HWD), South Carolina (Obermeier et al., 1987) that have been associated with earthquakes dating from 500 to 11,000 years B.P. (Talwani and Cox, 1985 and Weems et al., 1986). From studies of these paleoliquefaction features, at least seven, large, prehistoric earthquakes have occurred within the last 6000 years in the SCCP with an average occurrence rate, based on the three most recent events, of about 500 years (Talwani and Schaeffer, 2001).

Initial studies to investigate the paleoseismicity at the Hollywood site were performed by Martin (1990) and Martin and Clough (1994). Using geotechnical data (CPT, SPT and auger borings), they back calculated the peak ground acceleration, $\mathrm{a}_{\max }$, to be $0.3 \mathrm{~g}$ based on the Seed et al. (1984) method and 0.2g from the Ishihara (1985) method. They combined the Seed et al. (1984) and Ishihara (1985) procedures and found $\mathrm{a}_{\max }$ equal to $0.25 \mathrm{~g}$ for earthquake magnitude, $\mathrm{M}$, equal to 7.5 . They did not consider the effect of the soil deposit age on the results. 
More recent studies by Gheibi and Gassman (2015) and Gheibi (2016) used methods developed by $\mathrm{Hu}$ et al. (2002a, 2002b) and Leon et al. (2005) with sitespecific geotechnical data (e.g. $\left(\mathrm{N}_{1}\right)_{60}$ from the standard penetration test (SPT) and $\mathrm{q}_{\mathrm{c} 1}$ from the cone penetration test (CPT)) in the vicinity of paleoliquefaction features studied by Talwani and Schaeffer (2001) to estimate the minimum values of magnitudes and peak ground accelerations associated with earthquakes that occurred 546 $\pm 17,1021 \pm 30,3548 \pm 66$, and 5038 \pm 166 years B.P. Time dependent studies by Mesri et al. (1990) and Kulhawy and Mayne (1990) were used to account for the soil age. When the age of the earthquake was not considered, the minimum values of magnitude ranged from 7 to 7.2 and the corresponding acceleration ranged from 0.23 to $0.35 \mathrm{~g}$. The earthquake magnitude at the time of earthquake was found to be lower when accounting for age. For the most recent prehistoric earthquake with the age of $546 \pm 17$ years B.P., the magnitude ranged from 5.7 to 6.7 with corresponding acceleration ranging from 0.17 to $0.30 \mathrm{~g}$.

Given the uncertainties associated with back-analysis (e.g. factors related to liquefaction susceptibility, factors related to field observations and ground failure mechanisms, factors related to seismicity, and validity of in-situ testing techniques), Olson et al. (2005) recommended a regional approach using acceleration attenuation models in combination with cyclic stress methods to minimize the uncertainties associated with back-calculation of the peak ground acceleration and earthquake magnitude. They recommended first performing back-calculations using liquefaction evaluation procedures at individual sites to estimate a likely combination of $\mathrm{a}_{\max }$ and $\mathrm{M}$, then integrating the back-calculations at individual sites into a regional assessment 
to better assess the magnitude of the paleo-earthquake. This procedure overcomes some uncertainties related to time-depending mechanisms (aging) and changes in density resulting from liquefaction discussed by Olson et al. (2001). Use of this approach was illustrated by Green et al. (2005) for the Vincennes Earthquake that occurred around 6100 years B.P. in the Wabash Valley. Mechanical and chemical effects of aging were interpreted to be small for the soils within the study area, thus an aging correction factor was not applied to the measured penetration resistance data.

The purpose of this paper is to re-examine the geotechnical data collected at the Hollywood, SC site and back-calculate the minimum magnitude and acceleration required to initiate prehistoric liquefaction using regionally proper attenuation models (GMPEs) in combination with cyclic stress methods that account for time-dependent mechanisms. Attenuation models from Toro et al. (1997), Tavakoli and Pezeshk (2005), Atkinson (2008') and Pezeshk et al. (2011) are used with the semi-empirical cyclic stress method of Idriss and Boulanger (2008) and the time dependent approaches of Kulhawy and Mayne (1990) and Hayati and Andrus (2009). The results will be compared to earlier back-calculations by Martin and Clough (1994) and Gheibi and Gassman (2015).

\section{SITE STUDIED}

The Hollywood site is located $0.8 \mathrm{~km}$ northeast of the town of Hollywood, South Carolina along the east coast of the US as shown in Fig 1. Obermeier et al. (1987) reported finding 162 liquefaction features along the sidewalls of two flood control 
channels excavated at the site. Many of the observed features are sandblows as large as 2.4 meter in diameter from prehistoric earthquakes and some are minor fissures related to the Charleston earthquake of $1886(\mathrm{M} \approx 7$ (Talwani 2016)). Talwani and Cox (1985) and Weems et al. (1986) have used radiocarbon dates of the trapped organic material in and around sandblows to estimate the times of formation of the sandblows. Based on calibrated ages described in Talwani and Schaeffer (2001), times of sandblow formation range from 500 to 11,000 years B.P. and have been associated with four episodes: Episode A occurring 546 \pm 17 years B.P., Episode B $1021 \pm 30$ years B.P., Episode E $3548 \pm 66$ years B.P. and Episode F 5038 \pm 166 years B.P.

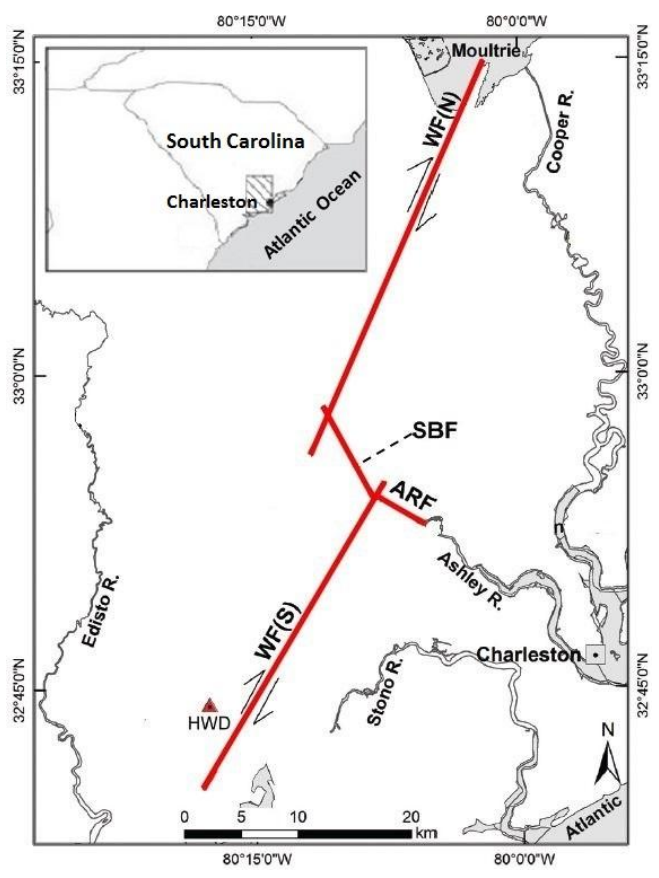

FIG. 1. Seismotectonic framework near the Hollywood site (adapted from DuraGomez and Talwani 2009).

The seismotectonic framework near the HWD site consists of the NE trending Woodstock fault (WF), which is cut and offset to the northwest along the Sawmill 
Branch fault (SBF) as shown in Fig. 1. Epicentral distances from WF and SBF are considered to be $25 \mathrm{~km}$ for Hollywood and hypocentral distances, rounded to the nearest $\mathrm{km}$ are one more $\mathrm{km}$ than the epicentral distances.

The in-situ data used in this study were obtained along an east-west exploration alignment that is parallel to one of the flood control channels and lies along the flank of a Pleistocene beach deposit with soils estimated to be about 120,000 to 130,000 years old (Weems et al., 1986). The alignment includes three CPTs (HWD-CPT-4, HWD-CPT-5 and HWD-CPT-6) and one SPT with energy measurements (HWDSPTE-1) that were performed as part of a larger study to investigate the effect of aging on the liquefaction potential of SCCP soils (e.g. Hasek (2016), Williamson and Gassman (2014), and Hayati et al. (2008)). Fig. 2 shows the CPT tip resistance and the SPT blow count profiles obtained at the site. Note that HWD-SPTE-1 is located near HWD-CPT-4. The water table depth was in the range of 1.7 to $2.3 \mathrm{~m}$ below the ground surface from 2007 to 2010. Laboratory index tests were performed on the SPT split spoon samples to characterize the soil and obtain the fines content.
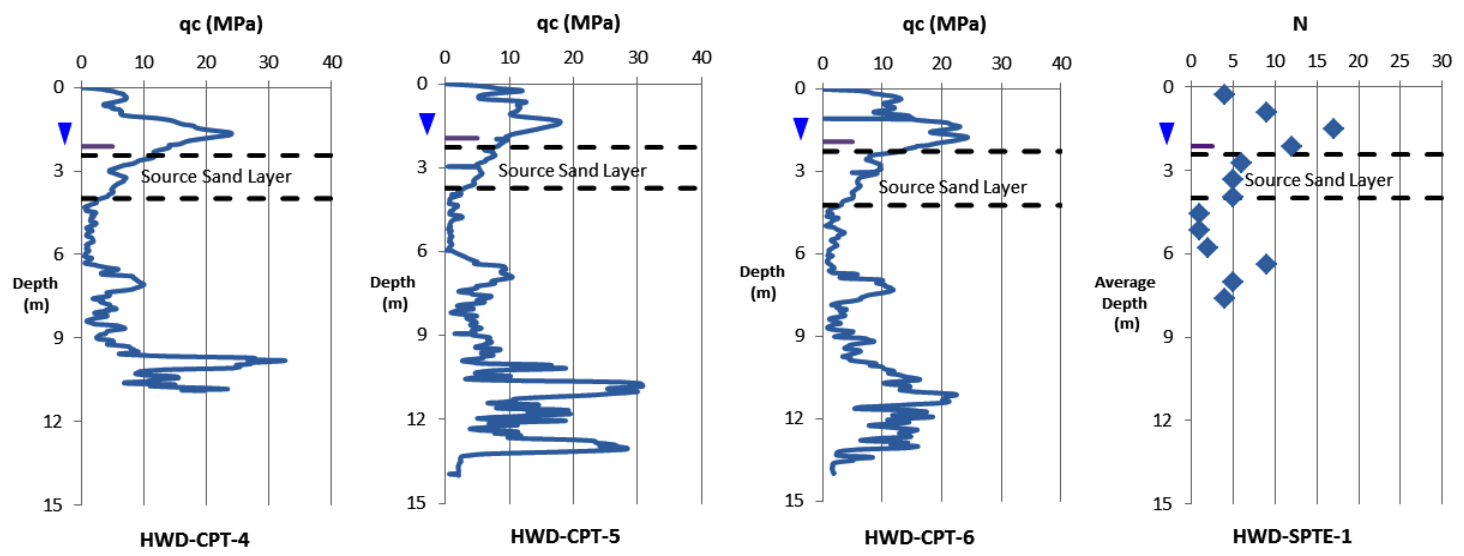

FIG. 2. CPT and SPT profiles at the Hollywood site. 
The soil classification chart of Robertson (1990) was used to obtain the soil profiles shown in Fig. 3. Samples from the SPT split spoon, near HWD-CPT-4, were used to classify the soil according to ASTM D422. The general soil profile along the testing alignment consists of about $2.30 \mathrm{~m}$ of silty sand (SM) with average CPT tip resistance as shown in Fig. 2 of about $15 \mathrm{MPa}$ (maximum of 18 to $24 \mathrm{MPa}$ ) and blow counts between 4 and 17. The underlying layer is the source sand layer and consists of 1.4 to $2 \mathrm{~m}$ of clean sand to silty sand (SP-SM) with an average tip resistance value of $6 \mathrm{MPa}$ and average blow count of 6 . This layer is underlain by a mixture of clayey silt to sandy silt and silty sand (SC-SM). The source sand layer identified in Fig. 3 is the layer most prone to liquefaction. This layer was identified using the interpretation of SPT blow counts, CPT tip resistance, excess pore water pressure, fines content and soil type. The fines content is in the range of 8 to $13 \%$ and excess pore pressures did not develop during the CPT push at any of the test locations. The equivalent clean sand tip resistance, $\left(\mathrm{q}_{\mathrm{c} 1 \mathrm{~N}}\right)_{\mathrm{cs}}$, and SPT blow counts are less than 160 and 30 in the source sand which are the boundaries for liquefiable/nonliquefiable soils per Robertson and Wride (1998) and Youd and Idriss (1997). 


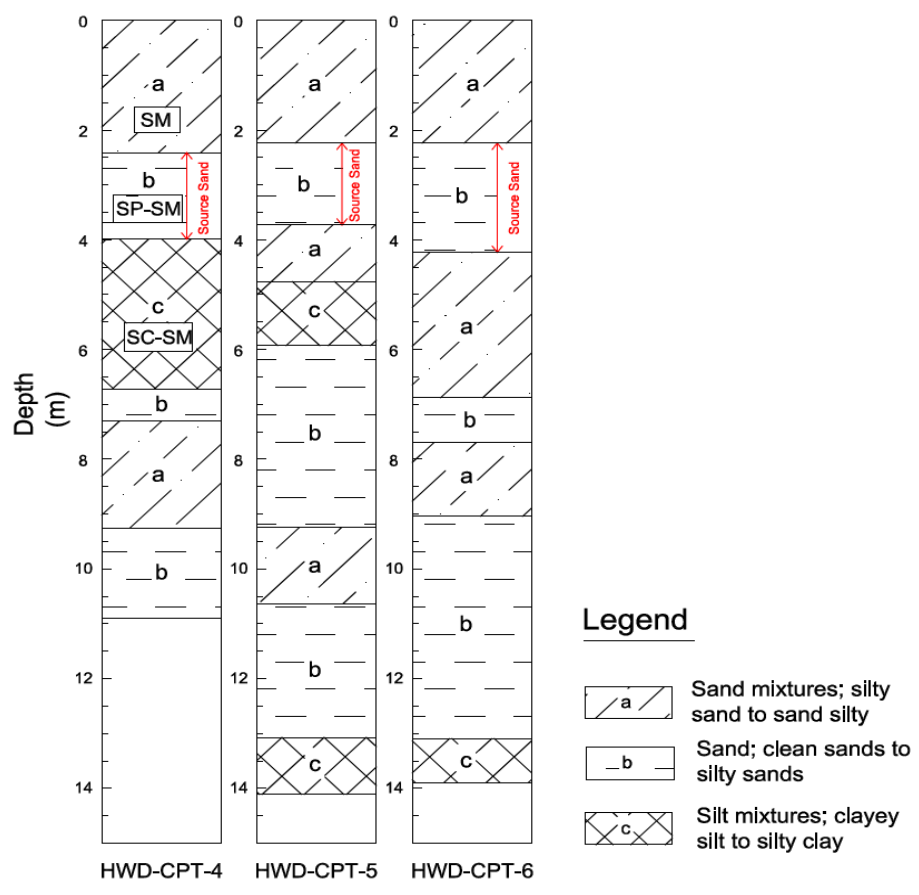

FIG. 3. Soil profile at the Hollywood site.

Earlier studies by Martin (1990) included eleven CPTs, eight SPTs and twelve auger borings. The soil profile was described to consist of about $2.6 \mathrm{~m}$ of clean, fine dense sand underlain by $2.3 \mathrm{~m}$ of clean, fine loose sand which was identified as the source of liquefied materials (Martin and Clough, 1994) and is in general agreement with the study herein. All fines were non-plastic silts.

\section{FRAMEWORK FOR AGE CORRECTION}

As proposed by Leon et al. (2005) the empirical correlations for liquefaction evaluation (i.e. Seed's Simplified method, as reported in Youd and Idriss 1997) that were developed based on freshly deposited or young (Holocene) soils can be used for older soil deposits as long as the currently measured penetration resistances are modified to account for the effect of time dependent processes (i.e. "aging"). For the 
study herein, two methods were used to account for aging by correcting the current cone penetration tip resistance to a representative post-earthquake penetration resistance value; the methodology of Kulhawy and Mayne (1990) (one of two methods proposed by Leon et al. (2005); the other being Mesri et al. (1990)) and the methodology of Hayati and Andrus (2009). The post-earthquake value of penetration resistance, rather than the pre-earthquake penetration resistance (as proposed by Leon et al. (2005) and used in Gheibi and Gassman (2014, 2015)), is used herein because the Energy Intensity equation (Pond and Martin, 1997) and the empirical relations between cyclic resistance ratio (CRR) and in situ measurements are almost exclusively based on field data measurements after earthquakes, not prior to earthquakes, and thus inherently account for disturbance (Olson et al., 2005).

The Kulhawy and Mayne (1990) method is based on collected SPT blow count data and relative density data as a function of soil particle size, $\mathrm{D}_{50}$, for aged fine to medium overconsolidated sands from four geologic periods. A correction factor, $\mathrm{C}_{\mathrm{A}}$, was proposed to describe the influence of aging (t) on the $\left(\mathrm{N}_{1}\right)_{60} / \mathrm{D}_{\mathrm{r}}^{2}$ ratio. This correction factor was extended to CPT data by Leon et al. (2005) and used herein to correlate the current penetration tip resistance to the post-earthquake values of penetration resistance, $\mathrm{q}_{\mathrm{c} 1}$ (post).

The methodology of Hayati and Andrus (2009) uses an updated liquefaction resistance correction factor, $\mathrm{K}_{\mathrm{DR}}$, given in Equation 1, where $\mathrm{t}$ is the time since initial deposition or critical disturbance in years, to find $\mathrm{CRR}_{\mathrm{k}}$ (the deposit resistancecorrected CRR) from Equation 2. $\mathrm{K}_{\mathrm{DR}}$ is based on data from over 30 sites in five 
countries and is used to account for the influence of age, cementation and stress history on CRR.

$$
\begin{aligned}
& \mathrm{K}_{\mathrm{DR}}=0.13 \cdot \log (\mathrm{t})+0.83 \\
& \mathrm{CRR}_{\mathrm{K}}=\mathrm{CRR} \cdot \mathrm{K}_{\mathrm{DR}}
\end{aligned}
$$

The average values of tip resistance $\left(\mathrm{q}_{\mathrm{c} 1}\right.$ (post) $)$, equivalent clean-sand value of the corrected tip resistance $\left(\left(\mathrm{q}_{\mathrm{clN}}\right)_{\mathrm{cs}}(\mathrm{post})\right)$, and cyclic resistance ratio $\left(\mathrm{CRR}_{(\mathrm{post})}\right)$, found using these two methods for the ages associated with earthquake Episodes A, B, E and F from Talwani and Schaeffer (2001) are summarized in Table 1 for the three CPT soundings. Note that in the Kulhawy and Mayne (1990) methodology, the aging correction is applied to the current measurements of penetration resistance $\left(\mathrm{q}_{\mathrm{c} 1}\right)$ to find the post-liquefaction penetration resistance and $\left(\mathrm{q}_{\mathrm{clN}}\right)_{\mathrm{cs} \text { (post) }}$ and $\mathrm{CRR}_{\text {(post) }}$ are obtained correspondingly as a function of $\mathrm{q}_{\mathrm{c} 1 \text { (post) }}$; whereas, in the Hayati and Andrus (2009) methodology, the aging correction is applied to the current CRR (which is a function of the current penetration resistance) to find post-liquefaction cyclic resistance ratio $\left(\mathrm{CRR}_{(\text {post })}\right)$ using Equation 1 and 2 where $\mathrm{t}$ is equal to time since critical disturbance in years as given by the age in Table 1. Each of these two methods is used separately to back-calculate the earthquake magnitudes and peak ground accelerations. As shown, in both cases the average values of tip resistance, equivalent clean-sand value of the corrected tip resistance, and cyclic resistance ratio corrected for age are less than when no aging correction is considered. The average $\mathrm{CRR}_{\text {(post) }}$ values found using Kulhawy and Mayne (1990) and Hayati and Andrus (2009) are in a good agreement. 
Table 1. Average values of $\mathbf{q}_{\mathrm{c} 1},\left(\mathbf{q}_{\mathrm{c} 1 \mathrm{~N}}\right)_{\mathrm{cs}}$ and $\mathrm{CRR}$ for source sand layer.

\begin{tabular}{|c|c|c|c|c|c|c|c|c|c|}
\hline \multirow{3}{*}{$\begin{array}{c}\text { Test } \\
\text { Location }\end{array}$} & \multirow{3}{*}{ Episode } & \multirow{3}{*}{$\begin{array}{c}\text { Age, } \\
\text { years B.P. }\end{array}$} & \multirow{2}{*}{\multicolumn{3}{|c|}{ No Age Correction }} & \multicolumn{4}{|c|}{ Age-Corrected } \\
\hline & & & & & & \multicolumn{3}{|c|}{$\begin{array}{c}\text { Kulhawy and Mayne } \\
\text { (1990) }\end{array}$} & \multirow{2}{*}{\begin{tabular}{|c|}
$\begin{array}{c}\text { Hayati and } \\
\text { Andrus (2009) }\end{array}$ \\
CRR \\
\end{tabular}} \\
\hline & & & $\begin{array}{c}\mathbf{q}_{\mathrm{cl}} \\
\text { (Mpa) }\end{array}$ & $\left(\mathbf{q}_{\mathrm{c} 1 \mathrm{~N}}\right)_{\mathrm{cs}}$ & CRR & $\begin{array}{c}\mathbf{q}_{\mathrm{c1}} \\
(\mathbf{M p a})\end{array}$ & $\left(\mathbf{q}_{\mathrm{c} 1 \mathrm{~N}}\right)_{\mathrm{cs}}$ & CRR & \\
\hline \multirow{4}{*}{ HWD-CPT-4 } & A & $546 \pm 17$ & \multirow{4}{*}{10} & \multirow{4}{*}{110} & \multirow{4}{*}{0.18} & 8 & 91 & 0.15 & 0.15 \\
\hline & B & $1021 \pm 30$ & & & & 8 & 90 & 0.15 & 0.14 \\
\hline & $E$ & $3548 \pm 66$ & & & & 8 & 88 & 0.14 & 0.14 \\
\hline & $\mathrm{F}$ & $5038 \pm 166$ & & & & 8 & 87 & 0.14 & 0.14 \\
\hline \multirow{4}{*}{ HWD-CPT-5 } & A & $546 \pm 17$ & \multirow{4}{*}{9} & \multirow{4}{*}{102} & \multirow{4}{*}{0.17} & 7 & 84 & 0.13 & 0.13 \\
\hline & $\mathrm{B}$ & $1021 \pm 30$ & & & & 7 & 83 & 0.13 & 0.13 \\
\hline & $\mathrm{E}$ & $3548 \pm 66$ & & & & 7 & 82 & 0.13 & 0.12 \\
\hline & $\mathrm{F}$ & $5038 \pm 166$ & & & & 7 & 81 & 0.13 & 0.12 \\
\hline \multirow{4}{*}{ HWD-CPT-6 } & A & $546 \pm 17$ & \multirow{4}{*}{10} & \multirow{4}{*}{121} & \multirow{4}{*}{0.21} & 8 & 100 & 0.17 & 0.16 \\
\hline & $\mathrm{B}$ & $1021 \pm 30$ & & & & 8 & 99 & 0.16 & 0.16 \\
\hline & $\mathrm{E}$ & $3548 \pm 66$ & & & & 8 & 97 & 0.16 & 0.15 \\
\hline & $\mathrm{F}$ & $5038 \pm 166$ & & & & 8 & 96 & 0.16 & 0.15 \\
\hline
\end{tabular}

\section{PALEOLIQUEFACTION BACK-ANALYSIS PROCEDURE}

Techniques proposed by Olson et al. (2005) and Green et al. (2005) were used in this study to reduce the uncertainties associated with back-analysis. Back-calculation was conducted using liquefaction procedures at each test location to determine the minimum required peak ground acceleration for different earthquake magnitudes. The obtained values of $M$ and $\mathrm{a}_{\max }$ were then combined with regional attenuation relationships to determine the proper combinations of $\mathrm{a}_{\max }-\mathrm{M}$.

\subsection{Back Analysis of Peak Ground Acceleration}

The peak ground acceleration at the surface was found using the following equation as a function of the earthquake magnitude and the cyclic stress ratio for a given earthquake $\left(\mathrm{CSR}_{\mathrm{M}=7.5, \sigma_{\mathrm{vc}=1}^{\prime}}\right)$ given by Idriss and Boulanger (2008): 


$$
\mathrm{a}_{\max }=\operatorname{CSR}_{\mathrm{M}=7.5, \sigma_{\mathrm{vc}}^{\prime}=1} * \operatorname{MSF} * \mathrm{~K}_{\sigma} *\left(\frac{\sigma_{\mathrm{v} 0}^{\prime} * \mathrm{~g}}{0.65 * \mathrm{r}_{\mathrm{d}} * \sigma_{\mathrm{v} 0}}\right)
$$

where $\sigma_{\mathrm{v} 0}$ is the vertical stress and $\sigma_{\mathrm{v} 0}^{\prime}$ is the vertical effective stress at depth $\mathrm{z}$, and $\mathrm{r}_{\mathrm{d}}$ is the reduction factor that considers the flexibility of soil column. The magnitude scaling factor (MSF) is used for earthquakes with magnitudes other than 7.5. $\mathrm{K}_{\sigma}$ is the overburden correction factor used to adjust CRR for the effect of effective overburden stress. The proposed relations of MSF, $\mathrm{r}_{\mathrm{d}}, \mathrm{K}_{\sigma}$ and $\mathrm{C}_{\mathrm{N}}$ of Idriss and Boulanger (2008) were used in this study.

For a factor of safety against liquefaction $\left(\mathrm{FS}_{\mathrm{liq}}\right)$ of one, CSR is equal to CRR and $\operatorname{CSR}_{\mathrm{M}=7.5, \sigma_{\mathrm{vc}=1}^{\prime}}$ is obtained for Equation 3 using the relation between CRR and $\left(\mathrm{q}_{\mathrm{c} 1 \mathrm{~N}}\right)_{\mathrm{cs}}$ given by Idriss and Boulanger (2008):

$$
\mathrm{CRR}_{\mathrm{M}=7.5, \sigma_{\mathrm{vc}}^{\prime}=1}=\exp \left\{\frac{\left(\mathrm{q}_{\mathrm{c} 1 \mathrm{~N}}\right)_{\mathrm{cs}}}{540}+\left(\frac{\left(\mathrm{q}_{\mathrm{c} 1 \mathrm{~N}}\right)_{\mathrm{cs}}}{67}\right)^{2}-\left(\frac{\left(\mathrm{q}_{\mathrm{c} 1 \mathrm{~N}}\right)_{\mathrm{cs}}}{80}\right)^{3}+\left(\frac{\left(\mathrm{q}_{\mathrm{c} 1 \mathrm{~N}}\right)_{\mathrm{cs}}}{114}\right)^{4}-3\right\}
$$

where $\left(\mathrm{q}_{\mathrm{c} 1 \mathrm{~N}}\right)_{\mathrm{cs}}$ is a function of $\mathrm{q}_{\mathrm{c} 1 \mathrm{~N}}\left(\mathrm{q}_{\mathrm{c} 1 \mathrm{~N}}=\frac{\mathrm{q}_{\mathrm{c} 1}}{\mathrm{P}_{\mathrm{a}}}\right.$ and $\left.\mathrm{q}_{\mathrm{c} 1}=\mathrm{q}_{\mathrm{c}} \times \mathrm{C}_{\mathrm{N}}\right)$, and the fines content, FC, as defined by Idriss and Boulanger 2008.

The peak ground acceleration obtained by Equation 3 is a function of earthquake magnitude. An example of an $a_{\max }-\mathrm{M}$ combination for a hypothetical site is shown in Fig. 4. The factor of safety for the combinations blow the line (shaded part) is more than one and so the $\mathrm{a}_{\max }-\mathrm{M}$ combinations above the line are proper for liquefaction initiation. 


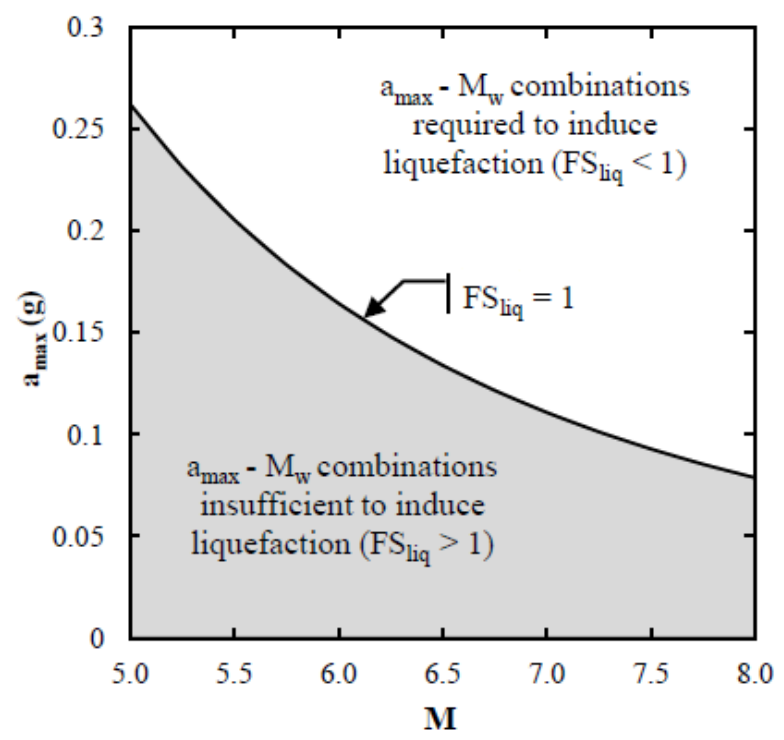

FIG. 4. An example of $a_{\max }-M$ combination to trigger liquefaction (adapted from Green et al. 2005).

\subsection{Regional Ground Motion Prediction Equations (GMPEs)}

Liquefaction evaluation procedures provide a wide range of $\mathrm{a}_{\max }-\mathrm{M}$ combinations for liquefaction initiation (see Fig. 4). Ground Motion Prediction Equations define maximum acceleration as a function of earthquake magnitude and site-to-source distance, R. As there are many combinations sufficient to induce liquefaction, the results of both methods are combined to find the intersection of the results to provide a reasonable combination of $\mathrm{a}_{\max }-\mathrm{M}$. Green et al. (2005) explained this concept in a schematic design in Fig. 5. As shown, the dashed line presents the $\mathrm{a}_{\max }-\mathrm{M}$ combination obtained using GMPE for a hypothetical site. The point of intersection is the minimum estimation of earthquake magnitude and peak ground acceleration for liquefaction initiation. 


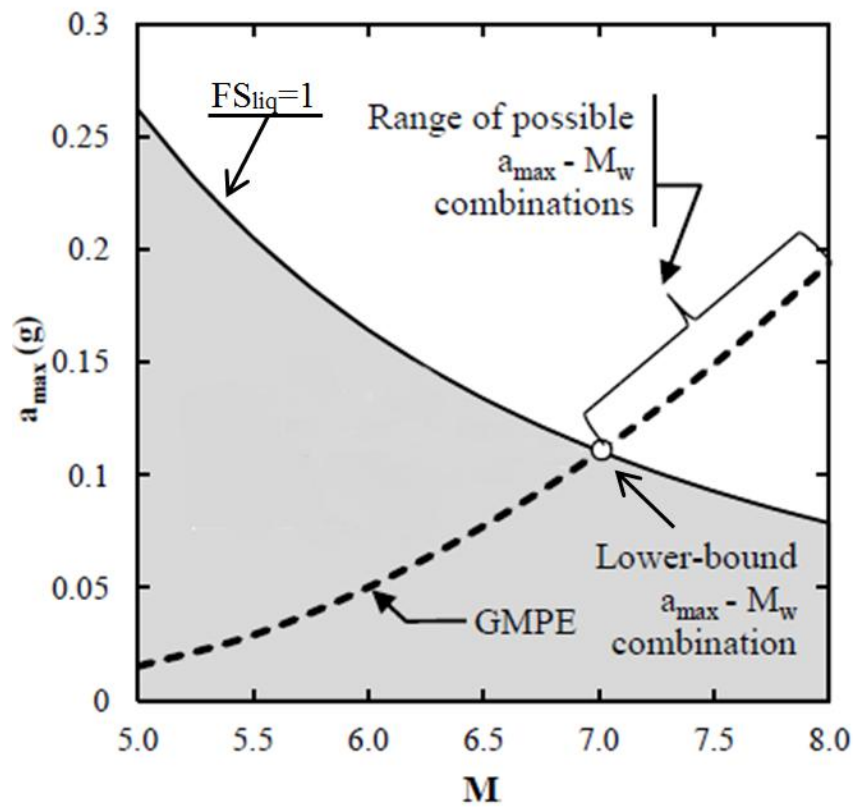

FIG. 5. Combined GMPE and liquefaction evaluation methods (adapted from Green et al. 2005).

Four ground motion prediction equations were selected using the 2014 Update of the United States National Seismic Hazard Maps. Toro et al. 1997 (T02), Tavakoli and Pezeshk 2005 (TP05), Pezeshk et al. 2011 (P11) and Atkinson 2008' (A08') that are regionally proper for the central and eastern US (CEUS) were used in this study (see Table 2). Atkinson 2008' refers to Atkinson 2008 as updated in Atkinson and Boore 2011. These models estimate the maximum acceleration at the bedrock, thus amplification factors (per Aboye et al., 2015) were used to modify the results obtained from GMPEs to obtain the peak ground acceleration at the surface. Results were compared to find the more robust estimation of $\mathrm{a}_{\max }-\mathrm{M}$ 
Table 2. Ground motion prediction models used for back-calculations (adapted from USGS update 2014).

\begin{tabular}{llll} 
Model & Abbreviation & $\begin{array}{l}\text { Site-to-Source } \\
\text { distance }\end{array}$ & Type \\
\hline Toro et al. (1997) & T02 & 1 to $500 \mathrm{~km}$ & Single Corner \\
Tavakoli and & TP05 & 1 to $1000 \mathrm{~km}$ & Hybrid \\
Pezeshk (2005) & & & \\
Atkinson (2008') & A08' & 1 to $500 \mathrm{~km}$ & Reference \\
Pezeshk et al. (2011) & P11 & 1 to $1000 \mathrm{~km}$ & Hybrid
\end{tabular}

Site-to-source distance is the closest distance to the rupture and is considered to be $25 \mathrm{~km}$ (see Fig. 1).

\section{RESULTS}

\subsection{Peak Ground Acceleration}

The age-corrected values of tip resistance and CRR in Table 1 were used in the procedure described in Section 4.1 to obtain the peak ground acceleration values for magnitudes ranging from 5 to 8 . As shown in Table 3, regardless of the approach used to account for the age of the earthquake, the age-corrected peak ground acceleration values are smaller than when a correction for the age of the earthquake is not made. Results also indicate that peak ground acceleration decreases as the 
earthquake magnitude increases. Fig. 6 shows the $\mathrm{a}_{\max }-\mathrm{M}$ combination for Episode A.

Results are the average of $\mathrm{a}_{\max }$ found for the three CPT test locations.

Table 3. Average values of $a_{\max }$ for source sand layer obtained using cyclic stress

method.

\begin{tabular}{|c|c|c|c|c|c|c|c|c|c|c|c|}
\hline \multirow[b]{3}{*}{ 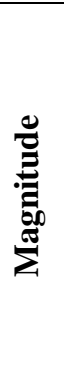 } & \multirow[b]{3}{*}{ 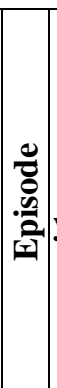 } & \multirow[b]{3}{*}{$\begin{array}{c}\text { Age, } \\
\text { years B.P. }\end{array}$} & \multicolumn{3}{|c|}{ HWD-CPT-4 } & \multicolumn{3}{|c|}{ HWD-CPT-5 } & \multicolumn{3}{|c|}{ HWD-CPT-6 } \\
\hline & & & \multirow{2}{*}{ 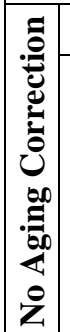 } & \multicolumn{2}{|c|}{ Age-Corrected } & \multirow{2}{*}{ 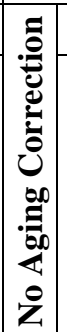 } & \multicolumn{2}{|c|}{ Age-Corrected } & \multirow{2}{*}{ 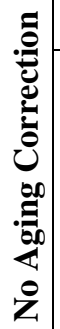 } & \multicolumn{2}{|c|}{ Age-Corrected } \\
\hline & & & & $\begin{array}{c}\text { Kulhawy } \\
\text { and } \\
\text { Mayne } \\
(1990)\end{array}$ & $\begin{array}{l}\text { Hayati } \\
\text { and } \\
\text { Andrus } \\
(2009)\end{array}$ & & $\begin{array}{c}\text { Kulhawy } \\
\text { and } \\
\text { Mayne } \\
(1990)\end{array}$ & $\begin{array}{l}\text { Hayati } \\
\text { and } \\
\text { Andrus } \\
(2009)\end{array}$ & & $\begin{array}{c}\text { Kulhawy } \\
\text { and } \\
\text { Mayne } \\
(1990)\end{array}$ & $\begin{array}{c}\text { Hayati } \\
\text { and } \\
\text { Andrus } \\
(2009)\end{array}$ \\
\hline \multirow{4}{*}{5} & A & $546 \pm 17$ & \multirow{4}{*}{0.4} & 0.36 & 0.39 & \multirow{4}{*}{0.4} & 0.31 & 0.34 & \multirow{4}{*}{0.5} & 0.39 & 0.41 \\
\hline & $\mathrm{B}$ & $1021 \pm 30$ & & 0.35 & 0.38 & & 0.31 & 0.33 & & 0.38 & 0.4 \\
\hline & $\mathrm{E}$ & $3548 \pm 66$ & & 0.34 & 0.38 & & 0.3 & 0.31 & & 0.37 & 0.38 \\
\hline & $\mathrm{F}$ & $5038 \pm 166$ & & 0.34 & 0.38 & & 0.3 & 0.3 & & 0.36 & 0.37 \\
\hline \multirow{4}{*}{6} & $\mathrm{~A}$ & $546 \pm 17$ & \multirow{4}{*}{0.4} & 0.29 & 0.31 & \multirow{4}{*}{0.3} & 0.25 & 0.27 & \multirow{4}{*}{0.4} & 0.31 & 0.33 \\
\hline & $\mathrm{B}$ & $1021 \pm 30$ & & 0.29 & 0.31 & & 0.25 & 0.26 & & 0.31 & 0.32 \\
\hline & $\mathrm{E}$ & $3548 \pm 66$ & & 0.28 & 0.31 & & 0.24 & 0.25 & & 0.3 & 0.31 \\
\hline & $\mathrm{F}$ & $5038 \pm 166$ & & 0.28 & 0.3 & & 0.24 & 0.25 & & 0.3 & 0.3 \\
\hline \multirow{4}{*}{7} & $\mathrm{~A}$ & $546 \pm 17$ & \multirow{4}{*}{0.3} & 0.22 & 0.24 & \multirow{4}{*}{0.2} & 0.19 & 0.21 & \multirow{4}{*}{0.3} & 0.24 & 0.25 \\
\hline & $\mathrm{B}$ & $1021 \pm 30$ & & 0.22 & 0.23 & & 0.19 & 0.2 & & 0.23 & 0.25 \\
\hline & $\mathrm{E}$ & $3548 \pm 66$ & & 0.21 & 0.23 & & 0.19 & 0.19 & & 0.23 & 0.23 \\
\hline & $\mathrm{F}$ & $5038 \pm 166$ & & 0.21 & 0.23 & & 0.18 & 0.19 & & 0.22 & 0.23 \\
\hline \multirow{4}{*}{7.5} & A & $546 \pm 17$ & \multirow{4}{*}{0.2} & 0.19 & 0.21 & \multirow{4}{*}{0.2} & 0.17 & 0.18 & \multirow{4}{*}{0.3} & 0.21 & 0.22 \\
\hline & $\mathrm{B}$ & $1021 \pm 30$ & & 0.19 & 0.2 & & 0.17 & 0.17 & & 0.2 & 0.21 \\
\hline & $\mathrm{E}$ & $3548 \pm 66$ & & 0.18 & 0.2 & & 0.16 & 0.17 & & 0.2 & 0.2 \\
\hline & $\mathrm{F}$ & $5038 \pm 166$ & & 0.18 & 0.2 & & 0.16 & 0.16 & & 0.19 & 0.2 \\
\hline \multirow{4}{*}{8} & A & $546 \pm 17$ & \multirow{4}{*}{0.2} & 0.17 & 0.18 & \multirow{4}{*}{0.2} & 0.15 & 0.16 & \multirow{4}{*}{0.2} & 0.18 & 0.19 \\
\hline & $\mathrm{B}$ & $1021 \pm 30$ & & 0.17 & 0.18 & & 0.14 & 0.15 & & 0.18 & 0.19 \\
\hline & $\mathrm{E}$ & $3548 \pm 66$ & & 0.16 & 0.18 & & 0.14 & 0.14 & & 0.17 & 0.18 \\
\hline & $\mathrm{F}$ & $5038 \pm 166$ & & 0.16 & 0.18 & & 0.14 & 0.14 & & 0.17 & 0.17 \\
\hline
\end{tabular}




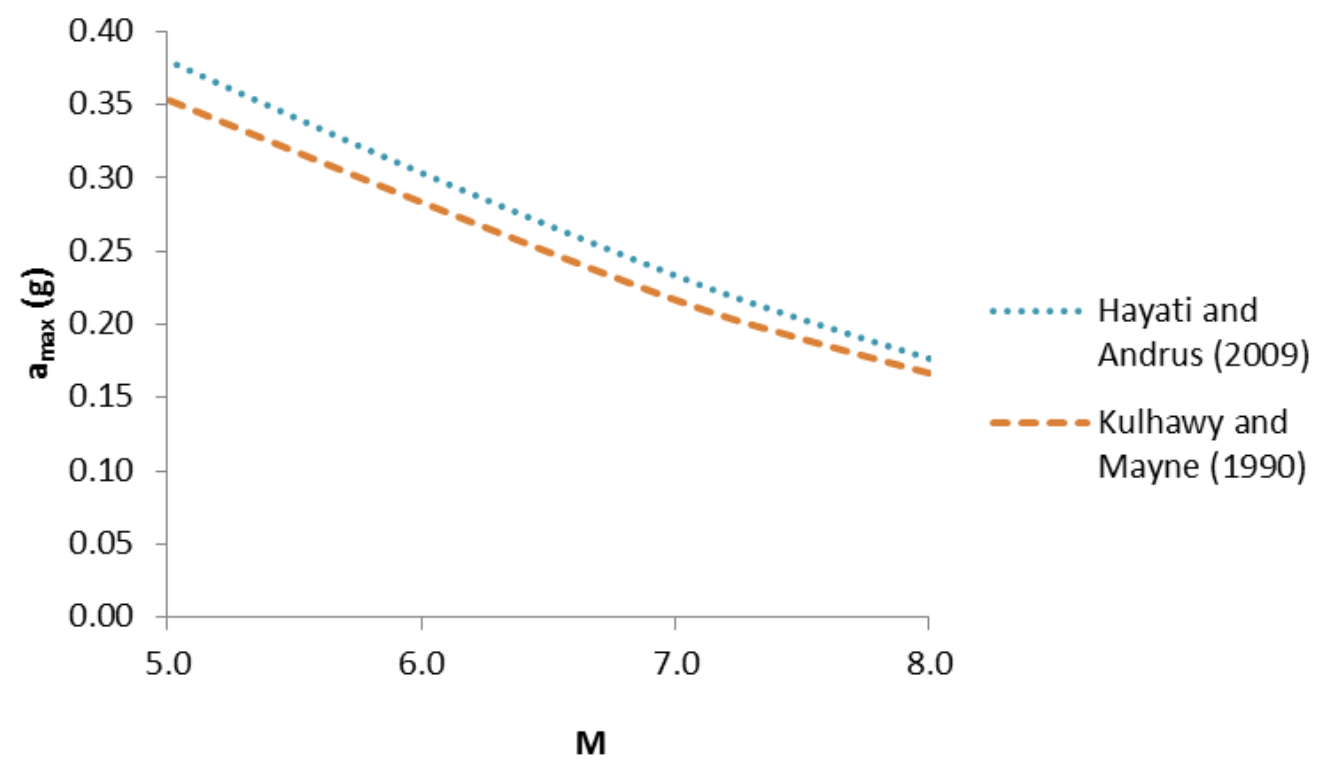

FIG. 6. Relation between $M$ and $a_{\max }$ for Hollywood site for Episode A.

\subsection{Earthquake Magnitude}

Table 4 indicates the minimum $\mathrm{a}_{\max }-\mathrm{M}$ at the time of earthquake found using the cyclic stress method and four GMPEs for each of the three test locations. Results obtained using the age-corrected values of tip resistance in Table 1 using both the Kulhawy and Mayne (1990) and Hayati and Andrus (2009) approaches were in a good agreement - M differed by up to 0.3 units and the $\mathrm{a}_{\max }$ differed by up to $0.02 \mathrm{~g}$. Results also indicate that the T02 model predicts slightly larger earthquake magnitudes (around 5\%) than the other three models.

Also shown in Table 4, an increase in the time of soil aging leads to a slight decrease in the required magnitude and peak ground acceleration for liquefaction initiation at time of earthquake. For instance if the age of earthquake is not considered, using the Pezeshk et al. 2011 model, the $\mathrm{a}_{\max }-\mathrm{M}$ at HWD-4 is 5.9-0.27g; whereas, for the most recent and oldest earthquakes (Episode A and F) the range of 
earthquake magnitude is 5.7 to 5.8 and 5.5 to 5.8 , respectively. The corresponding acceleration also decreases to around $0.24 \mathrm{~g}$ when the soil age is 546 years B.P. and ranges from 0.22 to $0.24 \mathrm{~g}$ when the soil age is 5038 years B.P.

Table 4. Range of $a_{\max }-M$ at each test location found using cyclic stress method and four GMPEs.

\begin{tabular}{|c|c|c|c|c|c|c|c|}
\hline \multirow{2}{*}{$\begin{array}{c}\text { Test } \\
\text { Location }\end{array}$} & \multirow{2}{*}{ Model } & \multirow{2}{*}{$\begin{array}{l}\text { Earthquake } \\
\text { Magnitudes }\end{array}$} & \multirow{2}{*}{$\begin{array}{c}\text { No } \\
\text { Correction } \\
\text { for Age }\end{array}$} & \multicolumn{4}{|c|}{ Age-Corrected } \\
\hline & & & & Episode A & Episode B & Episode E & Episode F \\
\hline \multirow{8}{*}{ HWD-CPT-4 } & \multirow{2}{*}{ T02 } & $\mathbf{M}$ & 6.15 & $6.0-6.1$ & $5.9-6.0$ & $5.9-6.0$ & $5.9-6.0$ \\
\hline & & $\mathbf{a}_{\max }$ & 0.25 & $0.22-0.23$ & 0.22 & $0.21-0.22$ & $0.21-0.22$ \\
\hline & \multirow{2}{*}{ TP05 } & M & 5.9 & $5.7-5.8$ & $5.7-5.8$ & $5.6-5.7$ & $5.6-5.7$ \\
\hline & & $\mathbf{a}_{\max }$ & 0.27 & $0.24-0.25$ & $0.24-0.25$ & $0.23-0.24$ & $0.23-0.24$ \\
\hline & \multirow{2}{*}{ A08' } & $\mathbf{M}$ & 5.8 & 5.7 & $5.6-5.8$ & $5.6-5.7$ & $5.6-5.7$ \\
\hline & & $\mathbf{a}_{\max }$ & 0.28 & 0.25 & $0.24-0.25$ & $0.23-0.24$ & $0.23-0.24$ \\
\hline & \multirow{2}{*}{ P11 } & $\mathbf{M}$ & 5.9 & $5.7-5.8$ & $5.6-5.8$ & $5.6-5.7$ & $5.5-5.8$ \\
\hline & & $\mathbf{a}_{\max }$ & 0.27 & 0.24 & $0.23-0.24$ & $0.22-0.24$ & $0.22-0.24$ \\
\hline \multirow{8}{*}{ HWD-CPT-5 } & \multirow{2}{*}{ T02 } & $\mathbf{M}$ & 6.15 & $5.9-6.0$ & 5.9 & 5.9 & $5.8-5.9$ \\
\hline & & $\mathbf{a}_{\max }$ & 0.26 & $0.21-0.22$ & $0.21-0.21$ & 0.21 & 0.20 \\
\hline & \multirow{2}{*}{ TP05 } & M & 5.8 & $5.6-5.7$ & $5.6-5.8$ & 5.6 & 5.6 \\
\hline & & $\mathbf{a}_{\max }$ & 0.28 & $0.23-0.25$ & $0.23-0.24$ & 0.23 & 0.23 \\
\hline & \multirow{2}{*}{ A08' } & $\mathbf{M}$ & 5.8 & $5.6-5.7$ & 5.6 & 5.6 & 5.5 \\
\hline & & $\mathbf{a}_{\max }$ & 0.29 & $0.24-0.25$ & $0.24-0.25$ & 0.23 & 0.23 \\
\hline & \multirow{2}{*}{ P11 } & M & 5.9 & $5.6-5.7$ & 5.6 & $5.5-5.6$ & 5.5 \\
\hline & & $\mathbf{a}_{\max }$ & 0.27 & $0.23-0.24$ & $0.23-0.24$ & $0.22-0.23$ & 0.22 \\
\hline \multirow{8}{*}{ HWD-CPT-6 } & \multirow{2}{*}{ T02 } & $\mathbf{M}$ & 6.5 & $6.2-6.3$ & $6.2-6.3$ & 6.2 & 6.2 \\
\hline & & $\mathbf{a}_{\max }$ & 0.28 & $0.23-0.25$ & $0.23-0.24$ & 0.23 & $0.22-0.23$ \\
\hline & \multirow{2}{*}{ TP05 } & M & 6.1 & 5.9 & 5.9 & $5.8-5.9$ & 5.8 \\
\hline & & $\mathbf{a}_{\max }$ & 0.32 & $0.27-0.28$ & $0.26-0.28$ & 0.26 & $0.25-0.26$ \\
\hline & \multirow{2}{*}{ A08' } & M & 6.1 & 5.9 & 5.9 & $5.8-5.9$ & 5.8 \\
\hline & & $\mathbf{a}_{\max }$ & 0.31 & $0.26-0.28$ & $0.26-0.27$ & $0.25-0.26$ & $0.25-0.26$ \\
\hline & \multirow{2}{*}{ P11 } & $\mathbf{M}$ & 6.3 & $5.9-6.1$ & $5.9-6$ & 5.9 & 5.9 \\
\hline & & $\mathbf{a}_{\max }$ & 0.29 & $0.24-0.26$ & $0.24-0.25$ & 0.24 & 0.24 \\
\hline
\end{tabular}

Table 5 presents the range of minimum earthquake magnitude and peak ground acceleration at each test location for each episode, for all attenuation models combined. The difference in earthquake magnitude and peak ground acceleration between different test locations is up to 0.4 units and $0.04 \mathrm{~g}$, respectively. 
Table 5. Range of $a_{\max }-M$ at each test location.

\begin{tabular}{|l|c|c|c|c|c|c|}
\hline \multirow{2}{*}{ Test Location } & \multirow{2}{*}{$\begin{array}{c}\text { Earthquake } \\
\text { Magnitudes }\end{array}$} & \multirow{2}{*}{$\begin{array}{c}\text { No } \\
\text { Correction } \\
\text { for Age }\end{array}$} & \multicolumn{4}{|c|}{ Age-Corrected } \\
\cline { 4 - 7 } & & Episode A & Episode B & Episode E & Episode F \\
\hline \multirow{2}{*}{ HWD-CPT-4 } & $\mathbf{M}$ & $5.8-6.2$ & $5.7-6.1$ & $5.6-6.0$ & $5.6-6.0$ & $5.5-6.0$ \\
& $\mathbf{a}_{\max }$ & $0.25-0.28$ & $0.22-0.25$ & $0.22-0.25$ & $0.21-0.24$ & $0.21-0.24$ \\
\hline \multirow{2}{*}{ HWD-CPT-5 } & $\mathbf{M}$ & $5.8-6.2$ & $5.6-6.0$ & $5.6-5.9$ & $5.5-5.9$ & $5.5-5.9$ \\
& $\mathbf{a}_{\max }$ & $0.26-0.29$ & $0.21-0.25$ & $0.21-0.25$ & $0.21-0.23$ & $0.20-0.23$ \\
\hline \multirow{2}{*}{ HWD-CPT-6 } & $\mathbf{M}$ & $6.1-6.5$ & $5.9-6.3$ & $5.9-6.3$ & $5.8-6.2$ & $5.8-6.2$ \\
& $\mathbf{a}_{\max }$ & $0.28-0.32$ & $0.23-0.28$ & $0.23-0.28$ & $0.23-0.26$ & $0.22-0.26$ \\
\hline
\end{tabular}

The results from the three test locations are combined for each Episode and the range of $M$ and $a_{\max }$ are shown in Table 6 . These results are compared with those obtained from earlier studies of Martin and Clough (1994) that did not consider the effect of the age of the soil deposit and Gheibi and Gassman (2015) pre-earthquake tip resistance data found using Mesri et al. (1990) and Kulhawy and Mayne (1990) time dependent approaches. Also shown are the results from a re-analysis of the data from Gheibi and Gassman (2015). $\quad M$ and $\mathrm{a}_{\max }$ were re-calculated using the postearthquake values of tip resistance and the Kulhawy and Mayne (1990) study to account for aging. This is consistent with the approaches to account for aging and back-calculate $a_{\max }$ used herein. The primary difference between the study herein and the re-analysis of Gheibi and Gassman (2015) is the method to find M: GMPE's were used in this study; whereas, an approach based on the Energy Intensity equation (Pond and Martin, 1997) was used previously. 
Table 6. Summary of estimated minimum peak ground acceleration and earthquake magnitudes at the Hollywood site.

\begin{tabular}{|c|c|c|c|c|c|c|}
\hline \multirow{2}{*}{ Study } & \multirow{2}{*}{$\begin{array}{l}\text { Earthquake } \\
\text { Magnitudes }\end{array}$} & \multirow{2}{*}{$\begin{array}{c}\text { No } \\
\text { Correction } \\
\text { for Age }\end{array}$} & \multicolumn{4}{|c|}{ Age-Corrected } \\
\hline & & & Episode A & Episode B & Episode E & Episode F \\
\hline \multirow{2}{*}{ This Study } & $\mathbf{M}$ & $5.8-6.5$ & $5.6-6.3$ & $5.6-6.3$ & $5.5-6.2$ & $5.5-6.2$ \\
\hline & $\mathbf{a}_{\max }$ & $0.25-0.32$ & $0.21-0.28$ & $0.21-0.28$ & $0.21-0.26$ & $0.20-0.26$ \\
\hline \multirow{2}{*}{$\begin{array}{l}\text { Gheibi and Gassman } \\
\text { (2015) }\end{array}$} & $\mathbf{M}$ & $7-7.2$ & $5.7-6.7$ & $5.5-6.5$ & $5.3-6.5$ & $5.2-6.5$ \\
\hline & $\mathbf{a}_{\max }$ & $0.23-0.35$ & $0.17-0.3$ & $0.17-0.30$ & $0.17-0.29$ & $0.16-0.29$ \\
\hline \multirow{2}{*}{$\begin{array}{l}\text { Re-analysis of Gheibi } \\
\text { and Gassman (2015) }\end{array}$} & M & $7-7.2$ & $6.7-6.9$ & $6.6-6.9$ & $6.6-6.8$ & $6.6-6.8$ \\
\hline & $\mathbf{a}_{\max }$ & $0.23-0.3$ & $0.20-0.26$ & $0.20-0.26$ & $0.20-0.26$ & $0.19-0.25$ \\
\hline \multirow{2}{*}{$\begin{array}{l}\text { Martin and Clough } \\
\text { (1994) }\end{array}$} & M & 7.5 & NA & NA & NA & NA \\
\hline & $\mathbf{a}_{\max }$ & 0.25 & NA & NA & NA & NA \\
\hline
\end{tabular}

\section{CONCLUSION}

The minimum earthquake magnitudes and peak ground accelerations associated with four episodes of prehistoric earthquakes at the Hollywood site in the South Carolina Coastal Plain were back analysed using in-situ geotechnical data, four Ground Motion Prediction Equations (T02, TP05, A08', P11) and two time-dependent procedures (Kulhawy and Mayne, 1990) and Hayati and Andrus, 2009) to correct for the age of the earthquake. Results indicated that the Toro et al. (1997) (T02) model predicts about 5\% larger values of earthquake magnitude than the other three models. The magnitudes found using GMPE's are an order of magnitude less than those found using the Energy Intensity equation. It was also shown that results obtained using Kulhawy and Mayne (1990) and Hayati and Andrus (2009) time-dependent approaches are in a general agreement. When the age of the earthquake was not 
considered, the minimum magnitude ranged from 5.8 to 6.5 and the corresponding peak ground acceleration ranged from 0.25 to $0.32 \mathrm{~g}$. When the age of the earthquake was considered, the earthquake magnitude was found to be 0.2 to 0.3 units lower depending on earthquake age and the GMPE model. For the most recent prehistoric earthquake with the age of $546 \pm 17$, the minimum magnitude ranged from 5.6 to 6.3 with corresponding acceleration ranging from 0.21 to $0.28 \mathrm{~g}$.

\section{ACKNOWLEDGEMENTS}

The SPT and CPT data used in this study were obtained with funds from the National Science Foundation, under grant number CMS-0556006. Any opinions, findings, and conclusions or recommendations expressed in this material are those of the author and do not necessarily reflect the views of the National Science Foundation.

\section{REFERENCES}

Aboye, S.A., Andrus, R.D., Ravichandran, N., Bhuiyan, A.H., and Harman, N. (2015). "Seismic site factors and design response spectra based on conditions in Charleston, South Carolina." Earthquake Spectra, Vol 31 (2): 723-744.

American Society for Testing and Materials (ASTM). Designation D 422, Standard Test Method for Particle Size Analysis of Soils, Annual Book of ASTM Standards, 408.

Atkinson, G.M., and Boore, D.M. (2011). "Modifications to existing ground-motion prediction equations in light of new data." Bulletin of the Seismological Society of America., Vol 101 (3): 1121-1135.

Dura-Gomez, I. and Talwani, P. (2009). "Finding faults in the Charleston area, South Carolina: 1, Seismological data.” Seismological Research. Letters., Vol 80 (5): 883-900. 
Gheibi, E. (2016). "Improved assessment of the magnitude and acceleration of prehistoric earthquakes in the South Carolina Coastal Plain" Ph.D. Dissertation to be Submitted to the University of South Carolina, Columbia. SC. DOI: 10.13140/RG.2.1.1484.2486

Gheibi, E., and Gassman S.L. (2014). "Reassessment of prehistoric earthquake accelerations at Sampit and Gapway sites in the South Carolina Coastal Plain." Proc. $10^{\text {th }}$ US National Conference on Earthquake Engineering Paper, DOI:10.4231/D3PV6B73Z.

Gheibi, E., and Gassman S.L. (2015). "Magnitudes of prehistoric earthquakes at the Hollywood, South Carolina, site." International Foundations Congress and Equipment Exposition (IFCEE) San Antonio, TX. 1246-1256, DOI: 10.1061/9780784479087.112.

Green, R.A., Obermeier, S.F., and Olson, S.M. (2005). "Engineering geology and geotechnical analysis of paleoseismic shaking using liquefaction effects: field examples." Journal of Engineering Geology, Vol 76: 263-293.

Hasek, M.J. (2016). "Liquefaction potential as related to the aging of SC outer coastal plain sands." Ph.D. Dissertation to be Submitted to the University of South Carolina, Columbia. SC.

Hayati, H., and Andrus, R.D. (2009). "Updated liquefaction resistance correction factors for aged sands." Journal of Geotechnical and Geoenvironmental Engineering, Vol 135(11): 1683-1692. DOI: 10.1061/ASCEGT.1943-5606.0000118.

Hayati, H., Andrus, R.D., Gassman, S.L., Hasek, M.J., Camp, W.M., and Talwani, P. (2008). "Characterizing the liquefaction resistance of aged soils." GEESD IV, Sacramento, CA.

Hu, K., Gassman, S.L., and Talwani, P. (2002a). "In-situ properties of soils at paleoliquefaction sites in the South Carolina Coastal Plain.” Seismological Research Letters, Vol 73 (6): 964-978.

Hu, K., Gassman, S.L., and Talwani, P. (2002b). "Magnitudes of prehistoric earthquakes in the South Carolina Coastal Plain from geotechnical data.” Seismological Research Letters, Vol 73 (6): 979991.

Idriss, I.M., and Boulanger, R.W. (2008). "Soil liquefaction during earthquakes." Monograph MNO12, Earthquake Engrg Research Institute. Oakland, CA. 
Ishihara, K. (1985). "Stability of natural soil deposits during earthquakes." Proceedig of $11^{\text {th }}$ Conference on Soil Mechanics and Foundation Engrg. International Society of Soil Mechanics and Foundation Engineers San Francisco, CA: 321-376.

Kulhawy, F.H., and Mayne, P.W. (1990). "Manual on estimating soil properties for foundation design.” Final Report, EL-6800, Electric Power Research Institute: 1439-6.

Leon, E., Gassman, S. L., and Talwani, P. (2005). “Accounting for soil aging on assessing magnitudes and accelerations of prehistoric earthquakes." Earthquake Spectra, Vol 21 (3): 737-759.

Martin, J.R. (1990). "Implications from a geotechnical investigation of liquefaction phenomena associated with seismic events in the Charleston, SC area" PhD Dissertation, Virginia Polytechnic Institute and State University.

Martin, J.R., and Clough, G.M. (1994). “Seismic Parameters from Liquefaction Evidence.” Journal of Geotechnical Engineering, Vol 120 (8): 1345-1361.

Mesri, G., Feng, T. W., and Banek, J. M. (1990). "Post densification penetration resistance of clean sands." Journal of Geotechnical Engineering, Vol 116 (7): 1095-1115.

Obermeier, S.F., Weems, R.E., and Jacobson, R.B. (1987). "Earthquake-induced liquefaction features in the coastal South Carolina region." US Geological Survey Open File Report, 87, 504.

Olson, S.M., Green, R.A., and Obermeier, S.F. (2005). "Geotechnical analysis of paleoseismic shaking using liquefaction features: a major updating." Journal of Engineering Geology, Vol 76: 235-261.

Olson, S.M., Obermeier, S.F., and Stark, T.D. (2001). "Interpretation of penetration resistance for back-analysis at sites of previous liquefaction.” Seismological Research Letters, Vol 72(1): 4659.

Petersen, M.D., Moschetti, M.P., Powers, P.M., Mueller, C.S., Haller, K. M., Frankel, A.D., Zeng, Y., Rezaeian, S., Harmsen, S.C., and Boyd, O.S., et al. (2014). "Documentation for the 2014 update of the United States national seismic hazard maps." U.S. Geological Survey Open-File Rept. 2014-1091, 243 pp.

Pezeshk, S., Zandieh, A., and Tavakoli, B. (2011). "Hybrid empirical ground-motion prediction equations for eastern north America using NGA models and updated seismological parameters." 
Bulletin of Seismological Society of America, Vol 101(4): 1859-1870. Paper DOI: $10.1785 / 0120100144$

Pond, E.C., and Martin, J.R. (1997). "Estimated magnitudes and accelerations associated with prehistoric earthquakes in the Wabash Valley region of the central United States." Seismological Research Letters, Vol 68(4): 611-623.

Robertson, P.K. (1990). "Soil classification using the cone penetration test." Canadian Geotechnical Journal, Vol 27: 151-158.

Robertson, P.K., and Wride, C.E. (1998). "Evaluating cyclic liquefaction potential using the cone penetration test.” Canadian Geotechnical Journal., Vol 35 (3): 442-459.

Seed, H.B., Tokimatsu, K., Harder, L.F., and Chung, R.M. (1984). “The Influence of SPT procedures in soil liquefaction resistance evaluations." Report No. UBC/EERC-84/15. University of California. Berkeley, Earthquake Engineering Research Center.

Talwani, P. (2016). "On the nature of intraplate earthquakes." Journal of Seismology., DOI $10.1007 / \mathrm{s} 10950-016-9582-8$.

Talwani, P., and Cox, J. (1985). "Paleoseismic evidence for recurrence of earthquakes near Charleston, South Carolina.” Science., Vol 229 (4711): 379-381.

Talwani, P., and Schaeffer, W.T. (2001). "Recurrence rates of large earthquakes in the South Carolina Coastal Plain based on the paleoliquefaction data." Journal of Geophysical Research., Vol 106 (B4): 6621-6642.

Tavakoli, B., and Pezeshk, S. (2005). "Empirical-stochastic ground-motion prediction for eastern north America.” Bulletin of Seismological Research Letter, Vol 95: 2283-2296.

Toro, G.R., Abrahamson, N.A., and Schneider, J.F. (1997). "Model of strong ground motions from earthquakes in central and eastern north America: best estimated and Uncertainties." Seismological Research Letters, Vol 68: 41-57.

Weems, R.E., Obermeier, S.F., Pavich, M.J., Gohn, G.S., and Rubin, M. (1986). "Evidence for three moderate to large prehistoric Holocene earthquakes near Charleston, South Carolina." Proceeding of $3^{\text {rd }}$ U.S. National Conference on Earthquake Engineering Charleston, South Carolina, Earthquake Engineering Research Institute, Oakland, CA., Vol 1: 3-13. 
Williamson, J.R. and Gassman, S.L. (2014). "Identification of liquefiable coastal plain soils using DMT, SPT and CPT profiles." Proceeding of ASCE GeoCongress Special Publication, Atlanta, GA.

Youd, T.L., and Idriss, I.M. (1997). "Proc. NCEER workshop on evaluation of liquefaction resistance of soils." National Center for Earthquake Engineering Research Technical Report NCEER-970022: 276.p. 